Research Article

Araştırma Makalesi

DOI: $10.24011 /$ barofd.992956
Bartın Orman Fakültesi Dergisi,

23(3): 917-925

15 December / Aralık, 2021
Journal of Bartin Faculty of Forestry

p-ISSN :1302-0943

e-ISSN :1308-5875

\title{
Orman Ürünleri İşletmelerinde Örgütsel Sinizmin Örgütsel Vatandaşlık Davranışı Üzerine Etkisinin Araştırılması: Trabzon Örneği
}

\author{
Nadir ERSEN ${ }^{1 *}$, Öner KARAYİĞİT ${ }^{1}$, İlker AKYÜZ², Bahadır Çağrı BAYRAM ${ }^{3}$ \\ ${ }^{1}$ Artvin Çoruh Üniversitesi, Artvin Meslek Yüksekokulu, Ormanc1lı Bölümü, 08000, ARTVİN \\ ${ }^{2}$ Karadeniz Teknik Üniversitesi, Orman Fakültesi, Orman Endüstri Mühendisliği, 61100, TRABZON \\ ${ }^{3}$ Kastamonu Üniversitesi, Orman Fakültesi, Orman Endüstri Mühendisliği, 37150, KASTAMONU
}

\section{Öz}

Bu çalışmada, Trabzon'da kereste ve mobilya sektöründe çalışanların örgütsel sinizm tutumları ve örgütsel vatandaşlık davranış sergileme düzeyleri; örgütsel sinizm alt boyutları ile örgütsel vatandaşlık davranış boyutu ve alt boyutları arasında anlamlı bir ilişkinin olup olmadığı; ve örgütsel sinizm alt boyutlarının örgütsel vatandaşlık ve alt boyutlarına etkisi belirlenmeye çalışılmıştır. Araştırma evrenini, Trabzon ilinde orman ürünleri sektöründe faaliyet gösteren işletmelerdeki çalışanlar oluşturmaktadır. Çalışma kapsamında 315 çalışana ulaşılmıştır. 305 anket değerlendirmeye alınmıştır. Yöntem olarak genellikle yüz yüze anket yöntemi kullanılmıştır. Çalışma sonucunda, örgütsel sinizm boyutlarının puan ortalaması düşük ve örgütsel vatandaşlık davranışı boyutu orta düzeyde çıkmıştır. Araştırma kapsamındaki çalışanların örgütsel sinizm tutumları ile örgütsel vatandaşlık davranışı arasında zayıf düzeyde ve negatif yönlü bir ilişki bulunmuştur. Örgütsel sinizm örgütsel vatandaşlık davranış1 üzerinde negatif yönde etkiye sahiptir.

Anahtar Kelimeler: Orman ürünleri sektörü, örgütsel sinizm, örgütsel vatandaşlık davranışı.

\section{Investıgation of The Effects of Organizational Cynicism on Organizational Citizenship Behavior in Forest Products Enterprises: The Example of Trabzon}

\begin{abstract}
In this study, organizational cynicism attitudes and organizational citizenship behavior levels of employees in the timber and furniture sector in Trabzon; whether there is a significant relationship between organizational cynicism sub-dimensions and organizational citizenship behavior dimension and sub-dimensions; and organizational cynicism sub-dimensions on organizational citizenship and its sub-dimensions were tried to be determined. The population of the research consists of the employees in the enterprises operating in the forest products sector in the province of Trabzon. Within the scope of the study, 315 employees were reached. 305 questionnaires were evaluated. As a method, face-to-face survey method was generally used. As a result of the study, the mean score of the dimensions of organizational cynicism was low and the dimension of organizational citizenship behavior was moderate. A weak and negative relationship was found between the organizational cynicism attitudes of the employees within the scope of the research and organizational citizenship behavior. Organizational cynicism has a negative effect on organizational citizenship behavior.
\end{abstract}

Keywords: Forest products sector, organizational cynicism, organizational citizenship behavior. 


\section{Giriş}

Günümüzün üretiminde makinelerin rolü giderek artıyor olsa da üretimin ana bileşeni insan olmaya devam etmektedir. Üretimin merkezinde insan olduğu sürece de bir örgütün en önemli ilkelerinin liyakat, istikrar, dürüstlük, adalet ve güven olması çalışanın yüksek performans göstermesi için olmazsa olmazların başında gelmektedir. Bunlardan bir veya birkaçının eksikliği çalışanın sinik tutum göstermesine neden olmakta, bu sinik duyguların örgütüne karşı olması ise örgütsel sinizmi doğurmaktadır. Örgütsel sinizm de çalışan kendisine adil davranılmadığ 1 ve yöneticiler ve diğer çalışanlar tarafından kendisinin kullanıldığı hissine kapılmakta ve çalışanda dürüstlükten yoksun ve liyakatin olmadığı bir yönetim varlığı düşüncesi oluşmaktadır. Bu tarz düşünceler ise çalışan performansının düşmesine, hatta diğer çalışanları etkileme özelliğiyle toplu bir performans düşüklüğüne sebep olabilmektedir. İşte örgütsel sinizmin yol açtı̆̆ı zararları fark edip önlem almak isteyen yönetici ve işverenler çalışanları için şirket içi birtakım değişikliklere gidip çalışanın etkili ve verimli çalışması için gerekli olan adımlar atmaya başlamışlardır. Uygun şartlar ve güvenli bir iş ortamı oluştuğunda ise çalışanlar kendisine verilen görevi yapmakla birlikte, verilen görevin de dışına çıkıp daha fazla sorumluluk aldığı ve şirketine artı değer kattığı gözlemlenmektedir. Çalışanın bu şekilde gönüllülük esasına dayanarak görev tanımının ötesinde bireysel olarak sergilediği davranışlara ise örgütsel vatandaşlık davranışı denmektedir. Çalışanın sergilediği bu örgütsel vatandaşlık davranışı, örgüt içi etkileşimle diğer çalışanlara da sirayet etmekte, grup verimliliğini arttırmakta, takım ruhunu geliştirmekte ve dolayısıyla örgüt performansının artmasını sağlamaktadır. Örgütsel vatandaşlık davranışı sergilenen işletmelerde eski çalışanlar yeni işe başlayanlara işin püf noktalarını anlatarak daha hızlı adapte olmasını sağlamakta, ekip içi uyumun sağlanmasına katkıda bulunmaktadır. Böylece ekip içi çatışmalarında önüne geçilerek performans kaybı önlenmektedir. Ayrıca, örgütsel vatandaşlık davranışı işe geç kalma, devamsızlık ve işten ayrılma gibi olumsuz davranışları azaltmakta, motivasyonu arttırıp iş tatminini sağlamakta önemli rol üstlenmektedir.

$\mathrm{Bu}$ çalışmada örgütsel sinizm ve örgütsel vatandaşlık davranışı kavramlarına yer verilmiş, örgütsel sinizmin örgütsel vatandaşlık davranışına etkisi belirlenmeye çalışılmıştır.

\section{1. Örgütsel Sinizm Kavramı}

Örgütsel sinizm ile ilişkin araştırmalar her ne kadar çok eskilere dayansa da 1990'lı yılların başında hız kazanmaya başlamıştır. Örgütsel sinizm, 1990'ların başından günümüze kadar gelen süreçte işletme yönetimi, insan kaynakları yönetimi, örgütsel davranış, hakla ilişkiler, iş etiği gibi farklı alanlardaki araştırmacıların da ilgisini çekmiştir (Tınaztepe, 2012). Birçok araştırmacının ilgisini çeken örgütsel sinizm ile ilgili bir çok tanım yapılmış olmasına rağmen (Andersson, 1996; Abraham, 2000; Bernerth vd., 2007), örgütsel sinizmin bilişsel, duyuşsal ve davranışsal olmak üzere üç temel bileşenden oluştuğu konusunda ortak bir fikir birliği bulunmaktadır (Balay vd., 2013). Örgütsel sinizm bileşenlerinden birincisi olan bilişsel sinizm, kurumdaki samimiyet, dürüstlük ve adalet eksikliğini ifade etmektedir. Bilişsel sinizmle karşı karşıya kalan çalışanlar, ilkelerin genellikle çıkar için feda edildiğini ve işletmelerinde ikilik, kurnazlık ve kişisel ilginin yaygın olduğunu düşünmektedir (Rehan vd., 2017; Durrah vd., 2019). Örgütsel sinizm bileşenlerinden ikincisi olan duyuşsal sinizm örgüte yönelik duygusal ve duygusal tepkileri ifade etmekte ve şiddetlenme, gerginlik, kaygı ve rahatsılık gibi psikolojik tepkileri içermektedir (Greenberg ve Baron, 2003; Durrah vd., 2019). Örgütsel sinizm bileşenlerinin sonuncusu olan davranışsal sinizm ise, örgütte sıklıkla kullanılan eleştirel ifadeleri ve olumsuz tutumları ifade etmektedir. Davranışsal sinizm, alaycı mizah, örgüt eleştirisi, olumsuz sözel olmayan davranış, örgütteki tutumların olumsuz yorumları ve örgütün gelecekteki eylemi hakkındaki alaycı tahminlerinden oluşmaktadır (Rehan vd., 2017; Durrah vd., 2019).

Ayrıca, örgütsel sinizm çalışanın üretkenlik ve performansını etkilediğinden dolayı zaman ve maddi kayıplara neden olmaktadır. Sinik bireylerin performansındaki olumsuz değişim, çalışanlar arasındaki psikolojik etkileşimden dolayı diğerlerini de olumsuz etkilemekte ve bunun sonucu olarak oluşabilecek performans kayıpları örgüt performansını doğrudan etkileyeceğinden dolayı örgütler için ciddi bir problem oluşturmaktadır (Uysal ve Yıldız, 2014; Torun, 2016). Örgütsel sinizmin her ne kadar örgüt açısından olumsuz sonuçları olduğu gözlemlense de bir takım olumlu sonuçları da olabilmektedir. Sinik çalışanlar eleştirel bir bakış açısıyla örgütün yaptıklarını ve stratejilerini sorgulayabilirler. Etik olmayan isteklere karşı boyun eğme eğilimin azalması da örgütsel sinizmin bir diğer olumlu sonucu olarak görülebilir (Torun, 2016).

\section{2. Örgütsel Vatandaşık Davranışı Kavramı}

Örgütsel vatandaşlık davranışı, resmi olarak talep edilmeyen veya doğrudan ödüllendirilmeyen ancak bir örgütün operasyonlarında işlevsel olabilen davranış olarak ifade edilmektedir (Smith vd., 1983). Rol üstü davranışlar olarak da ifade edilen örgütsel vatandaşlık davranışın boyutları öncülere göre farklılık göstermektedir (Smith vd., 1983; Organ, 1988; Lin, 1991; Willliams ve Anderson, 1991; Van Dyne vd., 1994; Podsakoff vd., 2000). Organ'1n 
geliştirdiği beş boyut (özgecilik, vicdanlılık, sportmenlik, nezaket ve sivil erdem) ise en fazla kullanılan örgütsel vatandaşlık boyutlarıdır. Örgütsel vatandaşlık davranış boyutlarından ilki olan özgecilik kısaca yardım etme ya da yardımseverlik olarak adlandırılmaktadır. Bireylerin belirli sorunları olduğunda, yardıma ihtiyaç duyduğunda veya yardım aradığında, özgecil insanlar onlara yardım etmek için ekstra yol kat ederler (Jahangir vd., 2004). Vicdanlılık organizasyonun asgari rol gereksinimlerinin çok ötesine geçen isteğe bağlı davranıştır (MacKenzie vd., 1993). Bir çalışan için daha fazla vicdanlılık, daha fazla sorumluluk ve daha az denetim anlamına gelmektedir (Podsakoff ve MacKenzie, 1997). Sportmenlik literatürde çok daha az ilgi görmüş bir vatandaşlık davranışı biçimidir. Sportmenlik özelliğine sahip kişiler sadece başkaları tarafından rahatsız edildiğinde şikayet etmez, aynı zamanda işler yolunda gitmediğinde bile olumlu bir tutum sergilemez, başkalarının önerilerine uymadığında gücenmez, çalışma grubunun iyiliği için kişisel çıkarlarını feda etmeye isteklidirler ve fikirlerinin reddedilmesini kişisel algılamazlar (Podsakoff vd., 2000). Nezaket çalışma arkadaşlarının problemlerini engellemeye çalışan ve yapıcı olan jestleri ve eylemleri açıklamaktadır. Nezaket sorunları önlemeye yardımcı olur ve zamanın yapıcı kullanımını kolaylaştırır (Jahangir vd., 2004; DasMohapatra vd., 2019). Sivil erdem bir bütün olarak kuruluşa makro düzeyde ilgiyi veya bağlılı̆̆1 temsil eder. Sivil erdem, yönetimine aktif olarak katılma, tehditler ve firsatlar için çevresini izleme ve büyük kişisel maliyetler pahasına da olsa kendi çıkarlarını gözetme isteğini gösterir (Podsakoff vd., 2000).

Ayrıca, örgütsel vatandaşlık davranışı bireye ve örgüte olumlu etkileri olmaktadır. Örgütsel vatandaşlık davranışları sergileyen örgütte sosyal mekanizmanın işleyişi daha kolaylaşır ve çalışanlar arasındaki çatışmalar azalmaktadır (Gürbüz, 2006). Bazı çalışmalarda da, örgütsel vatandaşlık davranışı gösteren kişilerin örgüt içindeki performansları diğer kişilere göre daha yüksek olduğu tespit edilmiştir (Organ ve Ryan, 1995; Podsakoff vd., 1996; Motowidlo, 2000). Chen ve arkadaşları (1998) ise örgütsel vatandaşlık davranışının personel değişim oranını azaltacağını ifade etmiştir.

\section{Materyal ve Metot}

\subsection{Araştırma Evreni ve Örneklemi}

Araştırma evrenini, Trabzon-Arsin organize sanayi sitesinde ve Trabzon mobilyacılar sitesinde faaliyet gösteren orman ürünleri (mobilya ve kereste) işletmelerindeki çalışanlar oluşturmaktadır. Anket formu mobilya ve kereste işletmelerinde çalışan 315 kişiye uygulanmıştır. Ancak, mantıksal hatalardan ve eksik ifadelerden dolayı 305 anket değerlendirmeye alınmıştır. Çalışanlara anket formu yüz yüze şeklinde uygulanmıştır.

\subsection{Veri Toplama Yöntemleri}

Çalışma kapsamından hazırlanan anket formu dört bölümden oluşmaktadır. Birinci bölüm çalışmaya katılan çalışanların demografik özelliklerini belirlemek amacıyla sorulan ifadelerden oluşmaktadır. İkinci bölümde katılımcıların örgütsel sinizm algılarını belirleyen ifadeler yer almaktadır ve bunun için Örgütsel Sinizm ölçeği kullanılmıştır. Diğer bölümde ise sırasıyla katılımcıların örgütsel vatandaşlık davranışlarını ölçmek için kullanılan ifadeler yer almaktadır. Örgütsel vatandaşlık davranışları için örgütsel vatandaşlık davranış ölçeği kullanılmıştır. Örgütsel sinizm ve örgütsel vatandaşlık davranışı ile ilgili hazırlanan ifadeler Beşli Likert ölçeğine göre hazırlanmıştır.

Örgütsel Sinizm Ölçeği: Örgütsel sinizm ölçeği olarak Brandes ve arkadaşları (1999) tarafindan geliştirilen, Karacaoğlu ve İnce (2012) tarafından Türkçe'ye uyarlanmış ve güvenirliği test edilmiş ve daha önceden birçok çalışmada da kullanılmış olan ölçek kullanılmıştır. Çalışmada kullanılan bu ölçek 13 sorudan ve 3 boyuttan (bilişsel, duygusal ve davranışsal) oluşmaktadır. Bilişsel boyutunda 5 ifade, duygusal boyutunda 4 ifade, davranışsal boyutunda 4 ifade yer almaktadır. Cronbach Alpha katsayısının 0.40'dan büyük olması ölçeğin güvenilir olduğunu göstermektedir (Özdamar, 1999). Örgütsel sinizm ölçeğinin Cronbach Alpha değeri 0.927 çıkmıştır. Örgütsel sinizmin alt boyutlarının Alpha değerleri ise şu şekilde çıkmıştır: Bilişsel boyutunun 0.911, duyuşsal boyutunun 0.968 ve davranışsal boyutunun 0.854 'tür. Örgütsel Sinizm ölçeğinin faktör analizine uygun olup olmadığını analiz etmek için Kaiser-Meyer-Olkin (KMO) ölçümü ve Bartlett's Küresellik Testi uygulanmıştır. Örgütsel sinizm ölçeğinin KMO değeri 0.910 ve Bartlett test sonucu 0.000 olarak bulunmuştur. Elde edilen bu sonuçlara göre verilerin faktör analizine uygun olduğu görülmektedir. Faktör analizi sonucunda örgütsel sinizm ölçeğinin 3 faktörden toplandığı bulunmuştur. Bu üç faktör toplam varyansın \%78.82'sini açıklamaktadır. 1. faktörde (Bilişsel) 5 ifade, 2. faktörde (Duyuşsal) 4 ifade ve 3. faktörde (Davranışsal) 4 ifade yer almaktadır. Örgütsel sinizm ölçeğinin literatür ile uyumlu olduğu görülmektedir. Bilişsel boyuttaki ifadelerin faktör yükleri 0.774 ile 0.840 arasında, duyuşsal boyuttaki ifadelerin faktör yükleri 0.887 ile 0.918 arasında ve davranışsal boyuttaki ifadelerin faktör yükleri ise 0.727 ile 0.819 arasında değişmektedir. 
Tablo 1. Örgütsel sinizm ölçeğinin faktör analizi.

\begin{tabular}{lccccc}
\hline & $\begin{array}{c}\text { Madde } \\
\text { Sayısı }\end{array}$ & Faktör Yükü & $\begin{array}{c}\text { Özdeğer } \\
\text { Değer }\end{array}$ & $\begin{array}{c}\text { Varyansı } \\
\text { Açılama } \\
\text { Yüzdesi }\end{array}$ & $\begin{array}{c}\text { Toplam } \\
\text { Varyans } \\
\text { Yüzdesi }\end{array}$ \\
\hline Faktör 1: Bilişsel & 5 & $0.774-0.840$ & 7.065 & 54.349 & 54.349 \\
Faktör 2: Duyuşsal & 4 & $0.887-0.918$ & 1.758 & 13.524 & 67.873 \\
Faktör 3: Davranışsal & 4 & $0.727-0.819$ & 1.423 & 10.947 & 78.82 \\
Kaiser-Mayer-Olkin & & & 0.910 & & \\
(KMO) & & & 0.000 & & \\
Barlett Küresellik Testi (p) & & & &
\end{tabular}

Örgütsel Vatandaşlık Davranışı Ölçeği: Bolat ve Bolat'ın (2008) otel işletmelerine yönelik yaptığı çalışmada kullandığ1 örgütsel vatandaşlık davranışı ölçeğinden yararlanılmıştır. Ölçek, yardımlaşma, vicdanlılık, centilmenlik, nezaket ve sivil erdem olmak üzere beş boyuttan ve 20 ifadeden oluşmaktadır. Yapılan faktör analizi sonucunda, aslında 5 boyuttan oluşan ölçek 4 boyutta toplanmıştır. Yardımlaşma boyutu ile nezaket boyutu tek bir boyut altında toplanmıştır. Polat ve Celep (2008) tarafından yapılan araştırmada benzer sonuç çıkmıştır. Bu çalışmada yardımlaşma boyutunda 8 ifade, vicdanlılık, sportmenlik ve sivil erdem boyutlarında ise 4 ifade yer almaktadır. Yardımlaşma boyutunun faktör yükleri 0.631 ile 0.796 arasında, vicdanlılık boyutunun faktör yükleri 0.638 ile 0.767 arasında, sportmenlik boyutunun faktör yükleri 0.547 ile 0.750 arasında ve son olarak sivil erdem boyutunun faktör yükleri 0.766 ile 0.835 arasında değişmektedir. Tablo 2'deki KMO (0.924) ve Barlett test $(\mathrm{p}=0.000)$ değerleri incelendiğinde ise ölçeğin faktör analizine uygun olduğu da görülmektedir. Örgütsel vatandaşlık davranışının alt boyutlarının güvenilirlik değerleri şu şekilde bulunmuştur: yardımlaşma 0.946, vicdanlılık 0.905 , sportmenlik 0.581 ve sivil erdem 0.901 'dir. Tüm ölçeğin güvenilirlik değeri ise 0.939 olarak bulunmuştur.

Tablo 2. Örgütsel vatandaşlık davranışı ölçeğinin faktör analizi.

\begin{tabular}{lccccc}
\hline Faktörler & $\begin{array}{c}\text { Madde } \\
\text { Sayısı }\end{array}$ & $\begin{array}{c}\text { Faktör } \\
\text { Yükü }\end{array}$ & $\begin{array}{c}\text { Özdeğer } \\
\text { Değer }\end{array}$ & $\begin{array}{c}\text { Varyansı } \\
\text { Açılama } \\
\text { Yüzdesi }\end{array}$ & $\begin{array}{c}\text { Toplam } \\
\text { Varyans } \\
\text { Yüzdesi }\end{array}$ \\
\hline Faktör 1: Yardımlaşma & 8 & $0.631-0.796$ & 10.268 & 51.342 & 51.342 \\
Faktör 2: Sivil erdem & 4 & $0.766-0.835$ & 2.171 & 10.855 & 62.197 \\
Faktör 3: Vicdanlılık & 4 & $0.638-0.767$ & 1.355 & 6.776 & 68.973 \\
Faktör 4: Sportmenlik & 4 & $0.547-0.750$ & 1.160 & 5.801 & 74.774 \\
Kaiser-Mayer-Olkin & & & \multicolumn{2}{c}{0.924} & \\
(KMO) & & \multicolumn{2}{c}{0.000} & \\
Barlett Küresellik Testi (p) & &
\end{tabular}

Çalışmada verilerin değerlendirilmesi için pearson korelasyon katsayı ve çoklu doğrusal regresyon analizi kullanılmıştır. Pearson korelasyon katsayısı, iki veya daha fazla değişken arasındaki ilişkinin derecesini temsil eden tanımlayıcı istatistiksel ölçüdür. Korelasyon katsayısının mutlak değeri 1'e yaklaştıkça değiş̧kenler arasındaki doğrusal ilişkinin derecesi artarken, 0’a yaklaştıkça ilişkinin derecesi azalmaktadır (Sheskin, 2000). Çalışmada kullanılan çoklu doğrusal regresyon analizi ise her bir bağımsız değişkenin bağımlı değişken üzerindeki kısmi etkisini ölçmektedir (Çimen, 2015).

\section{Bulgular ve Tartışma}

Örneklemi oluşturan katılımcıların \% 81.6'sı erkek ve \% 18.4'ü kadındır. Yaş grubu bakımından çalışanların \% 29.8'i 34-41 yaş aralığında, \% 29.5'i 42 yaş yaş ve üstü, \% 26.6's $26-33$ yaş aralığında ve \% 14.1'i 18-25 yaş aralığındadır. Anket çalışmasına katılan çalışanların \% 73.8'i evli, \% 26.2'si ise bekârdır. Katılımcıların çoğunluğu (\% 72.4) 3500 TL ve aşağısında bir ücret almaktadır. Eğitim durumu açısından çalışanların \% 62.1 'i lise mezunu, \% 23.6'sı önlisans mezunu, \% 10.7'si lisans veya lisansüstü mezunudur. Önlisans mezunu olanların oranı \% 10'un (\% 7.5) altındadır. Ankete katılanların çoğunluğunu (\% 82) işçi ve idari personel oluşturmaktadır. İşletmedeki çalışma süresi bakımından incelendiğinde, çalışanların \% 40'ından fazlası 5 yıl ve aşağı süre boyunca şuanki bulunduğu işletmede çalıştı̆̆ını söylemiştir. 6-10 yıl arasında çalışanların oranı \% 29.8 iken 11 yıl ve üzeri çalışanların oranı ise \% 23.3'tür. Katılımcıların \% 67.5'i mobilya sektöründe çalışırken, \% 32.5'i kereste 
sektöründe çalışmaktadır.

Tablo 3’teki tanımlayıcı analiz sonuçlarına göre, Trabzon'da orman ürünleri sektöründe çalışanların bilişsel $(\bar{x}=2.52)$ ve duyuşsal ( $\bar{x}=2.10)$ örgütsel sinizm boyutlarının puan ortalamaları düşük düzeyde iken, davranışsal $(\bar{x}=2.73)$ boyutunun puan ortalaması orta düzeyde çıkmıştır. Örgütsel sinizm boyutu genel olarak değerlendirildiğinde puan ortalamasının düşük düzeyde olduğu görülmektedir. Çalışanların örgütsel vatandaşlık davranışı boyutlarından yardımlaşma $(\bar{x}=4.28)$ boyutunun puan ortalaması yüksek düzeyde iken, sportmenlik $(\bar{x}=3.46)$, vicdanlılık $(\bar{x}=4.11)$ ve sivil erdem $(\bar{x}=4.12)$ boyutlarının puan ortalamaları orta düzeyde çıkmıştır. Örgütsel vatandaşlık davranışı $(\bar{x}=4.07)$ boyutu ise orta düzeydedir.

Tablo 3. Ölçeklerin ve alt boyutların tanımlayıcı istatistikleri.

\begin{tabular}{lcccc}
\hline Ölçek ve Alt Boyutlar & Min. & Mak. & $\overline{\boldsymbol{X}}$ & SS \\
\hline Örgütsel Sinizm Ölçeği & 1 & 5 & 2.4541 & 0.8125 \\
Bilişsel & 1 & 5 & 2.5186 & 0.9868 \\
Duyuşsal & 1 & 5 & 2.1035 & 0.9634 \\
Davranışsal & 1 & 5 & 2.7246 & 0.9832 \\
Örgütsel Vatandaşlık Davranışı Ölçeği & 1 & 5 & 4.0465 & 0.6216 \\
Yardımlaşma & 1 & 5 & 4.2751 & 0.7723 \\
Vicdanlılık & 1 & 5 & 4.1050 & 0.8057 \\
Sportmenlik & 1 & 5 & 3.4560 & 0.5856 \\
Sivil erdem & 1 & 5 & 4.1158 & 0.7427 \\
\hline
\end{tabular}

Tablo 4'teki korelasyon analizi sonuçları incelendiğinde, örgütsel sinizm boyutu ile örgütsel vatandaşlık davranış boyutu arasında zayıf düzeyde ( $\mathrm{r}=-0.204)$ ve negatif bir ilişki bulunmuştur. Örgütsel sinizm boyutu ile örgütsel vatandaşlık davranış alt boyutları arasındaki ilişki ise şu şekildedir: yardımlaşma $(\mathrm{r}=-0.162)$, vicdanlılık $(\mathrm{r}=-$ 0.196) ve sportmenlik ( $\mathrm{r}=-0.129)$ boyutları ile negatif ve ihmal edilecek ve sivil erdem boyutu ( $\mathrm{r}=-0.468)$ ile negatif ve zayıf düzeydedir. Örgütsel sinizm boyutunun alt boyutları ile örgütsel vatandaşlık davranış boyutu ve alt boyutları arasındaki ilişki incelendiğinde, örgütsel vatandaşlık davranış boyutu ile bilişsel (r=-0.627) ve duyuşsal ( $\mathrm{r}=-0.509)$ boyutları arasında negatif ve düşük düzeyde bir ilişki olduğu tespit edilmiştir. Örgütsel vatandaşlık davranış boyutu ile davranışsal boyutu arasında ise anlamlı bir ilişki bulunmamaktadır. Bilişsel boyutu ile yardımlaşma $(\mathrm{r}=-0.152)$, vicdanlılık $(\mathrm{r}=-0.161)$, sportmenlik $(\mathrm{r}=-0.141)$ boyutları arasında negatif ve ihmal edilecek düzeyde ve sivil erdem ( $\mathrm{r}=-0.24)$ ile negatif ve zayıf bir ilişki bulunmaktadır. Duyuşsal boyutu ile yardımlaşma $(\mathrm{r}=-0.221)$ ve vicdanlılık $(\mathrm{r}=-0.204)$ boyutları arasında negatif ve zayıf bir ilişki bulunurken, duyuşsal boyut ile sivil erdem ( $r=-0.19)$ negatif ve ihmal edilecek bir ilişki bulunmaktadır. Duyuşsal boyutu ile sportmenlik boyutu arasında ise anlamlı bir ilişki bulunmamaktadır. Davranışsal boyutu ile vicdanlılık boyutu ( $\mathrm{r}=-0.125)$ arasında negatif ve ihmal edilecek bir ilişki bulunmakta olup, yardımlaşma, sportmenlik ve sivil erdem boyutları arasında anlamlı bir ilişki bulunmamaktadır. Erdoğan ve Bedük (2013) tarafından yapılan çalışmada bilişsel sinizm ile nezaket ( $\mathrm{r}=-0.125)$, centilmenlik $(\mathrm{r}=-0.229)$ ve sivil erdem $(\mathrm{r}=-0.2)$ arasında anlamlı ve negatif; duyuşsal sinizm ile centilmenlik ( $\mathrm{r}=-0.295)$ ve sivil erdem ( $\mathrm{r}=-0.192)$ arasında anlamlı ve negatif; davranışsal sinizm ile özgecilik ( $\mathrm{r}=0.146)$ arasında anlamlı ve pozitif; davranışsal sinizm ile centilmenlik $(\mathrm{r}=-0.16)$ arasında anlamlı ve negatif bir ilişki bulunmuştur. Genel olarak değerlendirildiğinde ise örgütsel sinizm ile örgütsel vatandaşlık davranışı ( $\mathrm{r}=-0.137)$ arasında anlamlı ve negatif bir ilişki bulunmuştur. Tazegül Aydın (2017) tarafından öğretmenlere yönelik yapılan çalışmalarda da örgütsel sinizm ile örgütsel vatandaşlık davranışı arasında negatif bir ilişki olduğu bulunmuştur $(r=-0.125)$. Somunoğlu İkinci ve arkadaşları (2018) tarafından hastahane çalışanlarına yönelik yapılan çalışmada sportmenlik ile örgütsel sinizm boyutlarından olan bilişsel ( $\mathrm{r}=-$ 0.715), duyuşsal ( $\mathrm{r}=-0.831)$ ve davranışsal $(\mathrm{r}=-0.711)$ boyutları arasında anlamlı ve negatif yönlü bir ilişkinin olduğu tespit edilmiştir. Hastahane çalışanlarına yönelik başka bir çalışmada da örgütsel sinizm ile örgütsel vatandaşlık davranışı arasında negatif bir ilişki bulunmuştur (Lee ve Kim, 2018). Kamu çalışanlarına yönelik yapılan çalışmada duyuşsal sinizm ile örgütsel vatandaşlık davranışı arasında negatif yönlü ve anlamlı bir ilişki olduğu tespit edilmiştir ( $\mathrm{r}=-0.151)$ (Işı ve Candan, 2019). 
Tablo 4. Örgütsel sinizm boyutu ve alt boyutları ile örgütsel vatandaşlık davranışı boyutu ve alt boyutları arasındaki korelasyon değerleri.

\begin{tabular}{|c|c|c|c|c|c|c|c|c|}
\hline Değişkenler & 1 & 2 & 3 & 4 & 5 & 6 & 7 & 8 \\
\hline 1: Bilişsel & 1 & & & & & & & \\
\hline 2: Duyuşsal & $0.551^{* *}$ & 1 & & & & & & \\
\hline 3: Davranışsal & $0.556^{* *}$ & $0.482^{* *}$ & 1 & & & & & \\
\hline 4: ÖSÖ (Genel) & $0.873^{* *}$ & $0.801^{* *}$ & $0.807^{* *}$ & 1 & & & & \\
\hline 5: Yardımlaşma & $-0.152^{* *}$ & $-0.221^{* *}$ & -0.028 & $-0.162^{* *}$ & 1 & & & \\
\hline 6: Vicdanlılık & $-0.161^{* *}$ & $-0.204^{* *}$ & $-0.125^{*}$ & $-0.196^{* *}$ & $0.689^{* *}$ & 1 & & \\
\hline 7: Sportmenlik & $-0.141^{* *}$ & -0.088 & -0.083 & $-0.129^{*}$ & $0.523^{* * *}$ & $0.610^{* *}$ & 1 & \\
\hline 8: Sivil erdem & $-0.241^{* *}$ & $-0.191^{* *}$ & -0.060 & $-0.204^{* *}$ & $0.578^{* *}$ & $0.587^{* *}$ & $0.586^{* *}$ & 1 \\
\hline 9: ÖVDÖ (Genel) & $-0.201^{* *}$ & $-0.225^{* *}$ & -0.078 & $-0.204^{* *}$ & $0.911^{* *}$ & $0.856^{* *}$ & $0.743^{* *}$ & $0.786^{* *}$ \\
\hline
\end{tabular}

Korelasyon analizi sonuçlarına göre örgütsel sinizm boyutu ve alt boyutları ile örgütsel vatandaşlık davranışı boyutu ve alt boyutları arasında anlamlı ilişkilerin olduğu tespit edildikten sonra örgütsel sinizm ve alt boyutlarının örgütsel vatandaşlık ve alt boyutlarına etkisini belirlemek için regresyon analizinden yararlanılmıştır. Kullanılan regresyon analizinde örgütsel sinizm ve alt boyutları bağımsız değişkeni gösterirken, örgütsel vatandaşlık davranışı ve alt boyutları bağımlı değişkeni göstermektedir. Analiz sonucunda toplam 5 adet regresyon modeli oluşturulmuştur (Tablo 5).

Birinci model incelendiğinde, bağımsız değişkenlerden duyuşsal ve davranışsal boyutları \% 95 güven aralığında istatistiksel olarak anlamlı olup, bağımlı değişken olan yardımlaşma boyutu üzerinde sırasıyla negatif $(\beta=-0.233)$ ve pozitif ( $\beta=0.142$ ) yönde bir etkide bulunmaktadır. Yani, yardımlaşmanın gelişmesinde duyuşsallığın olumlu ve davranışsallığın olumsuz bir etkiye sahip olduğu ifade edilebilir. Modelde kullanılan bağımsız değişkenlerin (bilişsel, duyuşsal ve davranışsal) bağımlı değişkende (yardımlaşma) meydana gelen değişimi açıklama oranı \% 5.4 olarak gerçekleşmiştir. Bilişsel boyutunun ise istatistiksel olarak yardımlaşma boyutu üzerinde anlamlı bir etkisinin olmadığı bulunmuştur ( $\mathrm{p}>0.05)$. Oluşturulan modellerden ikincisi incelendiğinde, örgütsel sinizmin bilişsel, duyuşsal ve davranışsal boyutlarının örgütsel vatandaşlık davranışının vicdanlılık boyutunda meydana gelen değişimi açıklama oranı \% 4.5 olarak gerçekleşmiştir. Sadece duyuşsal boyutu istatistiksel olarak anlamlıdır ve duyuşsal ( $\beta=-0.163$ ) boyutu vicdanlılık boyutu üzerinde negatif bir etkiye sahiptir. Bilişsel ve davranışsal boyutlarının vicdanlılık üzerinde anlamlı bir etkisi bulunmamaktadır ( $\mathrm{p}>0.05)$. Sportmenlik boyutu için oluşturulan modelde, sportmenlik boyutu üzerinde örgütsel sinizm boyutlarının (bilişsel, duyuşsal ve davranışsal) istatistiksel olarak anlamlı bir etkisi bulunmamaktadır ( $>>0.05$ ). Diğer modelde, sivil erdem boyutunun \% 7.5'u bağımsız değişken olan bilişsel, duyuşsal ve davranışsal boyutları tarafından açıklanmaktadır. Bilişsel boyutunun sivil erdem boyutuna etkisi $(\beta=-0.251)$ olumsuzken, davranışsal $(\beta=0.137)$ boyutunun etkisi ise olumludur. Duyuşsal boyutunun sivil erdem boyutu üzerine anlamlı bir etkisi bulunmamaktadır ( $\mathrm{p}>0.05)$. Tablo 5 'de yer alan son modelde ise, örgütsel vatandaşlık davranışı boyutu üzerinde bilişsel $(\beta=-0.151)$ ve duyuşsal $(\beta=-0.189)$ boyutları negatif bir etkiye sahip olup, bu etki de istatistiksel olarak anlamlıdır. Bilişsel, duyuşsal ve davranışsal boyutlarının örgütsel vatandaşlık davranışı boyutunda meydana gelen değişimi açıklama oranı ise \% 6.5 olarak gerçekleşmiştir. Davranışsal boyutunun örgütsel vatandaşlık davranışı üzerinde etkisi bulunmamaktadır ( $\mathrm{p}>0.05)$. Ertosun ve arkadaşları (2016) yüksek örgütsel sinizm düzeyine sahip bir işletmede çalışanların örgütsel vatandaşlık davranışı sergileme sıklığının düşük olacağını ifade etmişlerdir. Özdemir ve Tekin (2018) örgütsel sinizmin alt boyutlarından biri olan duyuşsal boyutunun örgütsel vatandaşlık davranışının diğergamlık $(\beta=-0.253)$ ve sivilerdem $(\beta=-0.324)$ alt boyutlarını ve örgütsel sinizmin davranışsal boyutunun örgütsel vatandaşlık davranışının diğergamlık ( $\beta=-0.287)$, centilmenlik $(\beta=-0.237)$ ve sivil erdem $(\beta=-0.215)$ alt boyutlarını negatif olarak etkilediğini bulmuşlardır. Işık ve Candan (2019) ise örgütsel sinizmin örgütsel vatandaşlık davranışı üzerinde olumsuz bir etkisi olduğu sonucuna varmışlardır. Ancak bu etkinin istatistiksel açıdan anlamlı olmadığı sonucunu elde etmişlerdir $(\beta=-0.066 ; 0.214>0.05)$. 
Tablo 5. Örgütsel sinizm boyutlarının örgütsel vatandaşlık davranışı ve boyutları üzerindeki etkisine ilişkin regresyon sonuçları.

\begin{tabular}{|c|c|c|c|c|c|}
\hline \multirow{2}{*}{$\begin{array}{c}\text { Değişkenler } \\
\text { (Model 1) }\end{array}$} & \multicolumn{5}{|c|}{ Yardımlaşma } \\
\hline & B & Standart Hata & $\beta$ & $\mathbf{t}$ & $\mathbf{p}$ \\
\hline Sabit & 4.567 & 0.139 & & 32.797 & 0.000 \\
\hline Bilişsel & -0.081 & 0.057 & -0.103 & -1.414 & 0.158 \\
\hline Duyuşsal & -0.187 & 0.055 & -0.233 & -3.368 & 0.001 \\
\hline Davranışsal & 0.111 & 0.054 & 0.142 & 2.044 & 0.042 \\
\hline $\mathrm{R}=0.252$ & $\mathrm{R}^{2}=0.054$ & $F=6.775$ & Durbin & $n=1.735$ & 0.000 \\
\hline \multirow{2}{*}{$\begin{array}{l}\text { Değişkenler } \\
\text { (Model 2) }\end{array}$} & \multicolumn{5}{|c|}{ Vicdanlılık } \\
\hline & $\mathbf{B}$ & Standart Hata & $\beta$ & $\mathbf{t}$ & $\mathbf{p}$ \\
\hline Sabit & 4.548 & 0.147 & & 31.001 & 0.000 \\
\hline Bilişsel & -0.053 & 0.060 & -0.065 & -0.890 & 0.374 \\
\hline Duyuşsal & -0.136 & 0.058 & -0.163 & -2.334 & 0.020 \\
\hline Davranışsal & -0.008 & 0.057 & -0.010 & -0.139 & 0.890 \\
\hline $\mathrm{R}=0.212$ & $\mathrm{R}^{2}=0.045$ & $\mathrm{~F}=4.714$ & Durbin I & $n=1.718$ & 0.003 \\
\hline \multirow{2}{*}{$\begin{array}{c}\text { Değişkenler } \\
\text { (Model 3) }\end{array}$} & \multicolumn{5}{|c|}{ Sportmenlik } \\
\hline & $\mathbf{B}$ & Standart Hata & $\beta$ & $\mathbf{t}$ & $\mathbf{p}$ \\
\hline Sabit & 3.676 & 0.108 & & 34.040 & 0.000 \\
\hline Bilişsel & -0.078 & 0.044 & -0.132 & -1.772 & 0.077 \\
\hline Duyuşsal & -0.009 & 0.043 & -0.014 & -0.201 & 0.840 \\
\hline Davranışsal & -0.002 & 0.042 & -0.003 & -0.037 & 0.970 \\
\hline $\mathrm{R}=0.142$ & $\mathrm{R}^{2}=0.020$ & $F=2.061$ & Durb & $\begin{array}{l}\text { atson= } \\
1\end{array}$ & 0.105 \\
\hline \multirow{2}{*}{$\begin{array}{c}\text { Değişkenler } \\
\text { (Model 4) }\end{array}$} & \multicolumn{5}{|c|}{$\begin{array}{l}\text { Sivil erdem } \\
\end{array}$} \\
\hline & $\mathbf{B}$ & Standart Hata & $\beta$ & $\mathbf{t}$ & $\mathbf{p}$ \\
\hline Sabit & 4.503 & 0.133 & & 33.844 & 0.000 \\
\hline Bilişsel & -0.189 & 0.054 & -0.251 & -3.472 & 0.001 \\
\hline Duyuşsal & -0.092 & 0.053 & -0.119 & -1.733 & 0.084 \\
\hline Davranışsal & 0.103 & 0.052 & 0.137 & 1.987 & 0.048 \\
\hline $\mathrm{R}=0.274$ & $\mathrm{R}^{2}=0.075$ & $\mathrm{~F}=8.141$ & Durbin I & $n=1.849$ & 0.000 \\
\hline \multirow{2}{*}{$\begin{array}{c}\text { Değişkenler } \\
\text { (Model 5) }\end{array}$} & \multicolumn{5}{|c|}{ Örgütsel vatandaşlık davranışı ölçeği } \\
\hline & $\mathbf{B}$ & Standart Hata & $\beta$ & $\mathbf{t}$ & $\mathbf{p}$ \\
\hline Sabit & 4.374 & 0.112 & & 39.071 & 0.000 \\
\hline Bilişsel & -0.095 & 0.046 & -0.151 & -2.069 & 0.039 \\
\hline Duyuşsal & -0.122 & 0.045 & -0.189 & -2.734 & 0.007 \\
\hline Davranışsal & 0.061 & 0.044 & 0.097 & 1.401 & 0.162 \\
\hline $\mathrm{R}=0.255$ & $\mathrm{R}^{2}=0.065$ & $F=6.986$ & Durbin I & $n=1.747$ & 0.000 \\
\hline
\end{tabular}

\section{Sonuç ve Öneriler}

Üre Yapılan bu çalışmada ilk olarak mobilya ve kereste sektöründe çalışanların örgütsel sinizm algılarının ve örgütsel vatandaşlık davranış sergileme düzeylerinin belirlenmesi ve örgütsel sinizm ile örgütsel vatandaşlık davranışı arasındaki ilişkinin belirlenmesi amaçlanmıştır.Verileri değerlendirilmesi sonucunda, örgütsel sinizm boyutunun genel ortalaması düşük düzeyde çıkmıştır. Örgütsel sinizmim alt boyutları incelendiğinde, en yüksek puan ortalaması davranışsal boyutunda olduğu görülmektedir. En düşük ortalamaya sahip örgütsel sinizm boyutu ise duyuşsal boyutu çıkmıştır. Ankete katılan çalışanların örgütsel vatandaşlık davranış gösterme eğilimi yükseğe yakın düzeyde çıkmıştır. Örgütsel vatandaşlık davranışının alt boyutları incelendiğinde, yardımlaşma boyutu en fazla puana sahipken, sportmenliğin en az puana sahip olduğu bulunmuştur. Yapılan korelasyon analizi sonucunda, örgütsel sinizm ile örgütsel vatandaşlık davranış sergileme eğilimleri arasında negatif bir ilişki olduğu tespit edilmiştir. Örgütsel sinizm boyutu ile örgütsel vatandaşlık davranış alt boyutları (yardımlaşma, sportmenlik, vicdanlılık ve sivil erdem) arasında da negatif bir ilişkinin olduğu bulunmuştur. Örgütsel sinizm boyutunun alt boyutları ile örgütsel vatandaşlık davranış boyutu ve alt boyutları arasındaki ilişki incelendiğinde şu sonuçlar bulunmuştur:

- Örgütsel vatandaşlık davranış boyutu ile bilişsel ve duyuşsal boyutları arasında,

- Bilişsel boyutu ile yardımlaşma, vicdanlılık, sportmenlik ve sivil erdem boyutları arasında,

- Duyuşsal boyutu ile yardımlaşma, vicdanlılık ve sivil erdem boyutları arasında ve 
- Davranışsal boyutu ile vicdanlılık boyutu arasında negatif ve anlamlı ilişkiler tespit edilmiştir.

Korelasyon analizi sonuçlarına göre çalışanların örgütsel siniz tutumları ile örgütsel vatandaşlık davranışı gösterme eğilimleri arasında anlamlı ilişkilerin olduğu tespit edildikten sonra örgütsel sinizm tutumlarının örgütsel vatandaşlık davranışı üzerine etkisini belirlemek için regresyon analizi yapılmıştır ve 5 adet regresyon modeli oluşturulmuştur. Regresyon analizi sonucunda, örgütsel sinizmin alt boyutlarından olan bilişsel ve duyuşsal boyutların örgütsel vatandaşlık davranışı boyutu üzerinde negatif ve anlamlı bir etkiye sahip olduğu tespit edilirken, davranışsal boyutunun örgütsel vatandaşlık davranışı üzerinde etkisinin olmadığı tespit edilmiştir. Örgütsel vatandaşlık davranışı için oluşturulan diğer regresyon sonuçları ise şu şekilde çıkmıştır ve bütün sonuçlar istatistiksel olarak anlamlıdır.

- Yardımlaşmanın gelişmesinde duyuşsallığın pozitif ve davranışsallığın negatif bir etkiye,

- Duyuşsal boyutu sadece vicdanlılık boyutu üzerinde negatif bir etkiye,

- Bilişsel boyutu sivil erdem boyutu üzerinde negatif bir etkiye ve

- Davranışsal boyutu sivil erdem boyutu üzerinde pozitif bir etkiye sahiptir.

Bu sonuçlardan sonra örgütler ve yöneticiler için şu önerilerde bulunabiliriz;

- Öncelikle sinizm nedenlerinin belirlenmesi gerekmektedir, bu nedenleri belirleyebilmek için ise etkin bir insan kaynakları yönetimi oluşturmak önemlidir.

- Yönetim kadrosunun, ülkemizde henüz yeni yeni bilinmeye başlanan örgütsel sinizm ve örgütsel vatandaşlık gibi kavramlar üzerine bilgi sahibi olmaları için hizmet içi eğitimlere tabi tutulması sağlanabilir.

- Yöneticiler, çalışanların örgüte bağlılığını yükseltecek, motivasyonlarını arttıracak organizasyonlar gerçekleştirmeli, çalışanlara işleri konusunda destek olup, gerekli koçluğu yerinde ve zamanında çalışanına sağlaması sağlanmalıdır.

- Çalışanın yönetici bazlı sorun yaşamaması için, yönetimin adil, şeffaf ve güven esaslı bir yönetim tarzını benimsemelidir.

- Çalışana örgüt için değerli olduğu hissettirilmeli ve alınan kararlarda yüksek çalışan katılımı sağlanmalıdır.

\section{Kaynaklar}

1. Abraham, R. (2000). Organizational cynicism: bases and consequences. Genetic, Social, and General Psychology Monographs, 126(3), 269-292.

2. Andersson, L. (1996). Employee cynicism: an examination using a contract violation framework. Human Relations, 49(11), 1395-1418.

3. Balay, R., Kaya, A., Cülha, A. (2013). Örgüt kültürü ve örgütsel sinizm ilişkisi. C.Ü. İktisadi ve İdari Bilimler Dergisi, 14(2), 123-143.

4. Bernerth, J. B., Armenakis, A. A., Feild, H. S., Walker, H. J. (2007). Justice, cynicism, and commitment: a study of important organizational change variables. The Journal of Applied Behavioral Science, 43(3), 303-326.

5. Bolat, O. İ., Bolat, T. (2008). Otel işletmelerinde örgütsel bağlılık ve örgütsel vatandaşlık davranışı ilişkisi. Balıesir Üniversitesi Sosyal Bilimler Enstitüsü Dergisi, 11(19), 75-94.

6. Brandes, P., Dharwadkar, R., Dean, J. W. (1999). Does organizational cynicism matter? employee and supervisor perspectives on work outcomes. Eastern Academy of Management best papers proceedings, 150153.

7. Chen, X. P., Hui, C., Sego, D. J. (1998). The role of organizational citizenship behavior in turnover: conceptualization and preliminary tests of key hypotheses. Journal of Applied Psychology, 83, 922-931.

8. Çimen, M. (2015). Fen ve sağlık bilimleri alanlarında SPSS uygulamalı veri analizi. Palme Yayıncılık: Ankara, $314 \mathrm{~s}$

9. DasMohapatra, M., Satpathy, I., Patnaik, B. C. M. (2019). Impact of dimensions of organizational citizenship behaviour on job satisfaction in information technology sector. International Journal of Innovative Technology and Exploring Engineering, 8(12), 2503-2508.

10. Durrah, O., Chaudhary, M., Gharib, M. (2019). Organizational cynicism and its impact on organizational pride in industrial organizations. International Journal of Environmental Research and Public Health, 16, 1203-1218.

11. Erdoğan, P., Bedük, A. (2013). Örgütsel sinizm ile örgütsel vatandaşlık davranışı arasındaki ilişki: sağlık sektöründe bir araştırma. Sosyoteknik Sosyal ve Teknik Araştırmalar Dergisi, 3(6), 17-36.

12. Ertosun, A., Genç, N., Çekmecelioğlu, H. G. (2016). Örgütsel sinizm ile örgütsel vatandaşlık davranışı arasındaki ilişkilerin incelenmesi ve bir araştırma. Uluslararası Ekonomik Araştırmalar Dergisi, 2(1), 4353.

13. Greenberg, J., Baron, R. A. (2003). Behaviour in organizations: understanding and managing the human side of work. Prentice-Hall: Upper Saddle River, 691 pages. 
14. Gürbüz, S. (2006). Örgütsel vatandaşlık davranışı ile duygusal bağlılık arasındaki ilişkilerin belirlenmesine yönelik bir araştırma. Ekonomik ve Sosyal Araştırmalar Dergisi, 3(1), 48-75.

15. Işık, M., Candan, H. (2019). Kamu çalışanlarında örgütsel sinizmin örgütsel vatandaşlığa etkisi: Karaman ili örneği. International Journal of Economics, Politics, Humanities \& Social Sciences, 2(4), 265-281.

16. Jahangir, N., Akbar, M. M., Haq, M. (2004). Organizational citizenship behavior: its natüre and antecedents. BRAC University Journal, 1(2), 75-85.

17. Karacaoğlu, K., İnce, F. (2012). Brandes, Dharwadkar ve Dean'in (1999) örgütsel sinizm ölçeği Türkçe formunun geçerlilik ve güvenilirlik çalışması: Kayseri organize sanayi bölgesi örneği. Business and Economics Research Journal, 3(3), 77-92.

18. Lee, S. H., Kim, K. J. (2018). The effect of organizational cynicism on organizational citizenship behavior among hospital nurses : moderating effects of coaching leadership. The Korean Journal of Health Service Management, 12(3), 53-62.

19. Lin, S. J. (1991). Relationship between compensation equity, procedural justice, organizational commitment and organizational citizenship behavior. Doctoral dissertation, National Chengchi University, Taiwan.

20. MacKenzie, S. B., Podsakoff, M. F. and Fetter, R. (1993). The Impact of organizational citizenship behavior on evaluations of salesperson performance. Journal of Marketing, 57, 70-80.

21. Motowidlo, S. J. (2000). Some basic issues related to contextual performance and organizational citizenship behavior in human resource management. Human Resource Management Review, 10(1), 115126.

22. Organ, D. W. (1988). Organizational citizenship behavior: the good soldier syndrome. Lexington Books: Lexington, 132 pages.

23. Organ, D. W., Rayn, K. (1995). A meta-analytic review of attitudinal and dispositional predictors of organizational citizenship behavior. Personnel Psychology, 48, 775-802.

24. Özdamar, K. (1999). Paket programlar ile istatistiksel veri analizi. Kaan Kitabevi: Eskişehir, $535 \mathrm{s.}$

25. Özdemir, B., Tekin, E. (2018). Örgütsel sinizm'in örgütsel vatandaşlık davranışı üzerindeki etkisinin yapısal eşitlik modeli ile incelenmesi. İşletme Araştırmaları Dergisi, 10(2), 129-150.

26. Podsakoff, P. M., Mackenzie, S. B. (1997). The impact of organizationalcitizenship in organizational performance: review and suggestion for future research. Human Performance, 10, 133-151.

27. Podsakoff, P. M., MacKenzie, S. B., Bommer, W. H. (1996). Transformational leader behaviors and substitutes for leadership as determinants of employee satisfaction, commitment, trust, and organizational citizenship behaviors. Journal of Management, 22, 259-298.

28. Podsakoff, P. M., MacKenzie, S. B., Paine, J. B., Bachrach, D. G. (2000). Organizational citizenship behaviors: a critical review of the theoretical and empirical literature and suggestions for future research. Journal of Management, 26(3), 513-563.

29. Polat, S., Celep, C. (2008). Ortaöğretim öğretmenlerinin örgütsel adalet, örgütsel güven, örgütsel vatandaşlık davranışlarına ilişkin algıları. Educational Administration: Theory and Practice, 54, 307-331.

30. Rehan, M., Iqbal, M., Fatima, A., Nawabl, S. (2017). Organizational cynicism and its relationship with employee's performance in teaching hospitals of Pakistan. Int. J. Econ. Manag. Sci., 6, 1-6.

31. Sheskin, D. J. (2000). Handbook of parametric and nonparametric statistical procedures. Chapman and Hall/CRC: NewYork, 1016 pages.

32. Smith, C. A., Organ, D. W., Near, J. P. (1983). Organizational citizenship behavior: Its nature and antecedents. Journal of Applied Psychology, 68, 653-663.

33. Somunoğlu İkinci S., Ünalan, D., Yurdakoş, K. (2018). Examination of relations between organizational citizenship behavior and organizational cynicism in the health sector. Hacettepe Journal of Health Administration, 21(3), 511-528.

34. Tazegül Aydın, Y. (2017). İlkokul ve ortaokul öğretmenlerinin örgütsel sinizm ile örgütsel vatandaşlık davranışı ilişkisi: Ankara Altındağ ilçesi örneği. Yüksek Lisans Tezi, Balıkesir Üniversitesi Sosyal Bilimler Enstitüsü, Eğitim Bilimleri Anabilim Dalı, Balıkesir, $128 \mathrm{~s}$.

35. Tınaztepe, C. (2012). Örgüt içi etkin iletişimin örgütsel sinizme etkisi. Organizasyon ve Yönetim Bilimleri Dergisi, 4(1), 53-63.

36. Torun, Y. (2016). Personel güçlendirme ve işten ayrılma niyeti ilişkisinde örgütsel sinizmin aracılık rolü: örgütsel sinizm ölçeği geliştirmeye yönelik bir çalışma. Doktora Tezi, Marmara Üniversitesi Sosyal Bilimler Enstitüsü, Yönetim ve Organizasyon Anabilim Dalı, İstanbul, 428 s.

37. Uysal, H. T., Yıldız, M. S. (2014). İş gören performansı açısından çalışma psikolojisinin örgütsel sinizme etkisi. Uluslararası Sosyal Araştırmalar Dergisi, 7(29), 835- 849.

38. Van Dyne, L., Graham, J. W., Dienesch, R. M. (1994). Organizational citizenship behavior: constructre definition, measurement, and validation. Academy of Management Journal, 37, 765-802.

39. Williams, L. J., Anderson, S. E. (1991). Job satisfaction and organizational commitment as predictors of organizational citizenship and in-role behaviors. Journal of Management, 17, 601-617. 